\title{
The Gospel of Matthew: Reconfigured Torah
}

\author{
Richard B Hays ${ }^{1}$ \\ The Divinity School, Duke University \\ Research Associate: Department of New Testament Studies \\ University of Pretoria
}

\begin{abstract}
This essay surveys the evangelist Matthew's reading of Israel's Scripture. Rather than focusing only on Matthew's distinctive formula quotations, we must observe the subtler ways that Matthew evokes scriptural images and patterns. The essay highlights four major aspects of Matthew's reading of Scripture. (1) Matthew reads Israel's Scripture as a story that highlights election, kingship, exile, and messianic salvation as the end of exile. (2) Matthew reconfigures Torah into a call for radical transformation of the heart. (3) Matthew highlights Scripture's call for mercy, particularly by emphasizing Hosea 6:6 as the hermeneutical key to Torah. (4) Matthew interprets the mission to the Gentiles as the fulfilment of Israel's destiny and the active embodiment of the authority of the Son of Man (Dn 7:13-14) over the whole world. Jointly taken, these strategies of interpretation produce a striking reconfiguration of Israel's Torah.
\end{abstract}

\section{MATTHEW'S USE OF SCRIPTURE: OVERVIEW}

In the opening chapter of The Wound of Knowledge, Rowan Williams (1998:1) writes: "Christian faith has its beginnings in an experience of profound contradictoriness, an experience which so questioned the religious categories of its time that the resulting reorganization of religious language was a centuries-long task." The "experience of profound contradictoriness" is, of course, the crucifixion of Jesus as the event that somehow brought God's salvation to the world: "the paradox of God's purpose made flesh in a dead

\footnotetext{
${ }^{1}$ Prof Dr Richard Hays is Professor of New Testament at Duke Divinity School, Durham (NC), USA. This study is based upon a paper read to the Gospel of Matthew Seminar, Studiorum Novi Testamenti Societas, $58^{\text {th }}$ General Meeting, University of Catalonia in Barcelona, Spain, 31 July-4 August 2004. Prof Dr Richard B Hays is a research associate of Prof Dr Andries G van Aarde, Department of New Testament Studies, Faculty of Theology, University of Pretoria.
} 
and condemned man" (Williams 1998:3). The "reorganization of religious language" to which Williams (1998:1) refers is the subsequent process of reinterpretation of Israel's traditions and of the earliest stories about Jesus, in dialogue with one another, and in light of the events of the cross and resurrection. We see the beginnings of this "reorganization" within the New Testament itself in the New Testament writers' reinterpretations of Israel's Scripture.

Each of the canonical evangelists has a distinctive approach to interpreting Scripture. The Gospel of Mark, for example, reads Scripture in an indirect, allusive fashion that leads the reader into meditation on the mystery of the relation between Jesus and the God of Israel. As we encounter Mark's readings of Scripture, we are reminded of Williams's further comment about the difficulty and cost of encountering God's self-disclosure: "The greatness of the great Christian saints lies in their readiness to be questioned, judged, stripped naked and left speechless by that which lies at the center of their faith" (Williams 1998:1). From this point of view, we can perhaps better understand the speechlessness with which Mark's Gospel astonishingly ends: "They said nothing to anyone, for they were afraid." Mark bears witness to an early stage in the reorganization of Israel's religious language; his indirection and reticence attest the enormity of the claims he is making about Jesus' identity, as well as the cautiousness with which his community of readers might rightly receive such claims.

Matthew, however, has a very different approach. The aim of the present essay will be to examine the way in which the Gospel of Matthew advances the task of reorganizing Israel's religious language. What sort of a reader of Scripture is Matthew? Although he builds on the foundation laid by Mark's Gospel, Matthew shows little of Mark's restraint in pressing narrative claims about Jesus and linking them to Old Testament texts. Matthew is far more overt than Mark in his interpretative strategies; indeed, in many passages we find him providing explicit explanations of Mark's hints and allusions. Leaving nothing to chance, he repeatedly erects highway signs in large letters to direct his readers, making it unmistakably explicit that Jesus is the fulfilment of Israel's scriptures. Matthew has organized his material in a didactic, user-friendly fashion; Paul Minear (2000) has described this Gospel, in studied paradox, as a "training manual for prophets". It is therefore not without reason that when the fourfold Gospel canon was later assembled Matthew was placed first (see Stanton 2002; 1997:317-46). Nor was it without reason that Matthew became the Gospel most frequently cited by early Christian writers and that commentaries were written on it by Origen, Jerome, John Chrysostom, Theodore of Mopsuestia, and Cyril of Alexandria, to 
mention just some of the patristic authors who focused on this Gospel (see Luz 1989:19-22). (On the other hand, we have virtually no patristic commentaries on Mark.) Matthew successfully organized the Jesus tradition in a form that made it clear, harmonious, and accessible.

When we consider Matthew's use of the Old Testament, the first thing that springs to mind is his distinctive manner of introducing proof texts through a repeated formula in which the evangelist addresses the reader directly in an authorial voiceover: "This took place to fulfil what had been spoken through the prophet, saying .... " Ten quotations in Matthew appear under this rubric, with minor variations: Matthew 1:22-23, 2:15, 2:17-18, 2:23, 4:14-16, 8:17, 12:17-21, 13:35, 21:4-5, and 27:9. ${ }^{2}$ At least three other Old Testament quotations in the Gospel bear close affinities to this pattern of fulfilment citation: Matthew 2:5-6; 3:3, and Matthew 13:14-15. (In two of these three instances, Matthew breaks the formal pattern by placing the citation on the lips of characters in the story, and in the third [Mt 3:3] he avoids the verb $\pi \lambda \eta \rho \omega \theta \eta ़$ because the citation points to John the Baptist rather than to Jesus himself; the language of "fulfilment" is reserved by Matthew for quotations that prefigure Jesus.) Also closely related to the formula quotations are the words of Jesus at the time of his arrest in Gethsemane, affirming that "all this has taken place so that the scriptures of the prophets may be fulfilled" (Mt 26:56; cf $v 54$ ) - though in this case no specific quotation is adduced. This saying, alongside the thirteen authorial voiceovers, highlights Matthew's strong interest in the theme of fulfilled prophecy. Cumulatively, these passages frame Israel's Scripture as a predictive text pointing to events in the life of Jesus.

Matthew's emphasis on prediction and fulfilment has an evidently apologetic thrust: this rhetorical tactic seeks to validate claims about the identity of Jesus by grounding them in Israel's authoritative texts - presumably in opposition to other interpreters who would see Matthew's Christological claims as incongruous with Israel's Scripture. For this reason, a number of important studies have sought to reconstruct the social setting in which Matthew's apologetic arguments should be understood. If the interpretation of Scripture was a contested issue for Matthew, who were his opponents, and what was the specific historical context in which Matthew felt compelled to adduce these scriptural proof texts in defense of the story of Jesus? Although

\footnotetext{
${ }^{2}$ Another quotation in this format appears in some late manuscripts at 27:35, but this has apparently been interpolated by later scribes, under the influence of John 19:24. It is perhaps noteworthy that all ten authentic Matthean formula quotations cite texts from the prophets,

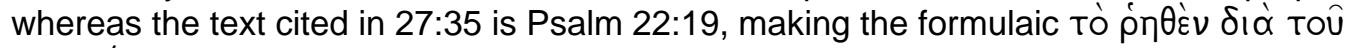
трофи́тоu not strictly appropriate. For discussion of these passages, see George M Soares Prabhu (1976), The formula quotations in the infancy narrative of Matthew. The most detailed discussion of the text-form of Matthew's citations is now M J J Menken (2004), Matthew's Bible: The Old Testament text of the evangelist.
} 
it is impossible to be certain of the details, there is a strong consensus among recent scholars that the text must have been written in a setting (such as Antioch in Syria) where Jewish Christianity found itself in fierce competition with the synagogue and its scribal leadership in the period following the destruction of the Jerusalem Temple (see Luz 1989:79-93; Overman 1990; 1996; Stanton 1992; Saldarini 1994; Sim 1998).

Krister Stendahl's (1968) classic study The School of St Matthew focused on the eclectic use of different Old Testament textual traditions in the formula quotations and argued that they were the product of a JewishChristian scribal "school" that combed through various ancient texts and versions to find passages that could be interpreted as messianic proof texts. More recent studies have demonstrated, however, that the same redactional tendencies at work in the formula quotations are to be found also in other scriptural citations in Matthew's Gospel. Consequently, Matthew himself should be seen as the controlling synthetic imagination responsible for assembling this material (see Stanton 1992:346-63).

Matthew has front-loaded these formula quotations in the opening chapters of his Gospel. Four of the ten formula quotations appear in the birth and infancy narratives; if we add the fulfilment citations in Matthew 2:5-6 and $3: 3$, we find that nearly half of these weighty hermeneutical directives are placed in the plot structure even before the baptism of Jesus, and still another accompanies his initial proclamation of the kingdom in Galilee (Mt 4:14-16). This cluster of fulfilment quotations near the beginning of the Gospel conditions readers to expect that nearly everything in the story of Jesus will turn out to be the fulfillment of something pre-scripted by the prophets. Israel's sacred history is presented by Matthew as an elaborate figurative tapestry designed to point forward to Jesus and his activity.

The rhetorical impact of these formula quotations is so powerful that they have tended to dominate our understanding of how Matthew appropriates Scripture. (Indeed, because of Matthew's eventual placement at the head of the New Testament canon, these quotations have exerted an even more sweeping influence: they dominate popular Christian understanding of how the Old Testament is to be read.) Recently, however, Donald Senior (1997:89115) has contributed an important essay entitled The Lure of the Formula Quotations in which he argues convincingly that this one distinctive feature of Matthew's citation practice should not be permitted to monopolize our attention. Our understanding of Matthew's use of Scripture will be far too narrow, Senior contends, if we are enraptured by the "siren song" of the formula quotations (Senior 1997:90). These citations, to be sure, express a theological perspective that pervades Matthew's Gospel - as expressed in certain key programmatic statements such as Jesus' declaration in the 
Sermon on the Mount that he has come not to abolish the Law but to fulfil it (Mt 5:17). Yet precisely this saying suggests that we must reckon with a Matthean hermeneutical program considerably more comprehensive than a collection of a dozen or so proof texts. In what sense does Jesus fulfill the Law? If Jesus has come to fulfil every jot and tittle of the Law (Mt 5:18), we should expect Matthew to develop a far more wide-ranging account of the accordance between Scripture and Gospel. And indeed, that is just what we find in this narrative: A diverse and complex use of Scripture. According to Senior's tally, there are sixty-one Old Testament quotations in the Gospel. That means that the formula quotations constitute, even by the most generous estimate, only about one fifth of Matthew's total. And that does not even begin to reckon with the hundreds of more indirect Old Testament allusions in the story. $^{3}$

Above and beyond the question of citations of particular texts, we must reckon also with Matthew's use of typology, his deft narration of tales that Senior (1997:115) describes as "shadow stories from the Old Testament". Through this narrative device, with or without explicit citation, the reader is encouraged to see Jesus as the fulfilment of Old Testament precursors, particularly Moses, David, and Isaiah's Servant figure. ${ }^{4}$ It is of course impossible to survey all this material in the present chapter, but we shall examine a few key passages that shed light on Matthew's strategies for reading Scripture.

\section{HOW DOES MATTHEW CARRY FORWARD THE STORY OF ISRAEL?}

\subsection{The Genealogy (1:1-17)}

In contrast to Mark's strategy of plunging abruptly into the story at the point of Jesus' baptism, Matthew anchors the story of Jesus in Israel's history by opening his Gospel with a genealogy. This genealogy may strike many readers today as nothing other than a dull list of names. The modern reader's first inclination upon encountering this material is to suspect that the author of this gospel might fairly be characterized by Samuel Johnson's complaint about one of his contemporaries: "He is not only dull himself, he is the cause of dullness in others." While Matthew's genealogy is hardly an electrifying way to begin a narrative - in contrast to the immediate dramatic action of Mark's

\footnotetext{
${ }^{3}$ Senior (1997:89) points out that "The Nestle-Aland appendix lists 294 implicit citations or allusions in Matthew."

${ }^{4}$ For the most detailed and methodologically elegant study of one of these narrative typologies, see Allison (1993), The new Moses: A Matthean typology. My doctoral student Leroy Huizenga is at work on a dissertation in which he argues that the Matthean Jesus should also be understood in typological relation to the figure of Isaac in the Akedah tradition.
} 
opening paragraph - it actually performs several important hermeneutical functions.

First, it ensures continuity between Israel's story and the story that Matthew is about to narrate. Unlike Mark's Jesus, Matthew's Jesus does not burst on the scene out of nowhere; he is the heir of a familial line that stretches back through forty-two generations to Abraham. (This point holds despite the odd fact that the genealogy traces Jesus' lineage through Joseph [1:16], who, according to Mt 1:18-25, is not Jesus' biological father.) This genealogy prepares the reader to interpret Jesus as the heir of the promises to Abraham, the consummation of Israel's epic story that began in the patriarchal narratives of Genesis. Even Matthew's opening words in 1:1,

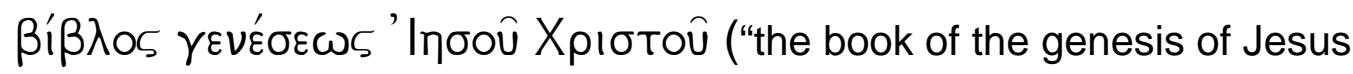
Christ") reinforce this association with the Torah's opening book. (The phrase ßiß account of the creation of man and woman, and in Gn 5:1 LXX, where it introduces a list of Adam's descendants.) If so, as W D Davies and Dale Allison (1988:149-54) have suggested, this opening line may function as a title for the Gospel as a whole, suggesting that the story of Jesus is in fact a "new Genesis," the story of an eschatological redemption that begins the world anew. The redeemer figure who accomplishes this redemption is, moreover, "Jesus Christ, son of David, son of Abraham". This identification links the new creation inextricably to the past of Israel. Each name in the genealogy, particularly the better-known ones, evokes the recollection of Israel's story. Thus, Jesus' identity is grounded in Israel's story, and the detailed genealogy functions for the reader as an "Aufruf zur Erinnerung", summoning the reader to locate the entire Gospel narrative within the history sketched in these opening lines (see Alkier 2002:18-19).

Second, the genealogy periodizes the story of Israel into three great chapters leading up to the birth of Jesus, each chapter encompassing fourteen generations: Chapter 1, from Abraham to David; Chapter 2, from David to the exile; and Chapter 3, from the exile to the Messiah (Mt 1:17). This way of charting Jesus' genealogy highlights his Davidic lineage - and therefore his messianic identity. Matthew underscores this point by referring to Jesus in the final phrase of the genealogy as "the Christ"; the definite article signals the titular sense of this term. Perhaps even more significantly, Matthew 1:17 unmistakably signals that the coming of Jesus portends the end of Israel's exile: "So all the generations from Abraham to David are fourteen generations; and from David to the deportation to Babylon, fourteen generations; and from the deportation to Babylon to the Messiah, fourteen generations." The periodization of the genealogy outlines the plot of Israel's 
story. From the founding promise to Abraham there is an ascending movement to the Davidic kingship (Mt 1:2-6a), then a decline into exile (Mt 1:6b-11), followed by a period of obscurity awaiting the advent of the Messiah (Mt 1:12-16). It is very striking that Moses does not figure in this sketch of the plot of Israel's story; it is a story about promise, kingship, exile, and return - a story in which the Law of Sinai plays no explicit part. This does not mean, of course, that Matthew has no interest in the Mosaic Law - quite the contrary. Nonetheless, his narrative strategy of beginning with the genealogy has the effect of highlighting Jesus' identity as messianic king, rather than as lawgiver.

The strong emphasis given to Israel's exile in Matthew's genealogy imparts a particular shape to the history that the reader is asked to remember: the story of Israel is a story that juxtaposes God's covenant faithfulness (as signified by the promise to Abraham ${ }^{5}$ and the promise to David) of an everlasting kingdom [2 Sm 7:12-14]) to Israel's unfaithfulness (as signified by David's sinful taking of the wife of Uriah [Mt 1:6, alluding to 2 Sm 11-12] and by the checkered history of the kings that followed him, leading up to the deportation to Babylon). Thus, the genealogy functions for the reader who remembers the complexity of the stories evoked by Matthew's list of names, as a "Sündenspiegel" in which Israel sees its sins reflected (Alkier 2002:20). Yet, at the same time, the structure of the genealogy clearly points forward in hope, for it leads finally to "the Messiah" Jesus, the one who "will save his people from their sins" (Mt 1:21) (Repschinski 2004). Here we see an example of the hermeneutical significance of the genealogy: it compels the reader to understand that the "sins" from which God's people are saved are not merely petty individual transgressions of a scrupulous legal code, but rather the national sins of injustice and idolatry that finally led to the collapse of the Davidic monarchy and the Babylonian captivity. ${ }^{6}$

Finally, Matthew's genealogy introduces four anomalies into the story, through the appearance of four women in the list of Jesus' ancestors: Tamar (Mt 1:3), Rahab (Mt 1:5), Ruth (Mt 1:5), and Bathsheba, the wife of Uriah (Mt 1:6). Since the names of women were not ordinarily included in genealogical lists, the reader might well wonder why these four are singled out particularly in view of the omission of well-known matriarchs such as Sarah,

\footnotetext{
${ }^{5}$ On the importance of Abrahamic covenant traditions in Matthew, see Brawley (2004:127148).

${ }^{6}$ Thus, the opening chapter of Matthew's Gospel is theologically consonant with Wright's (1996), Jesus and the victory of God, which interprets the significance of Jesus' work as bringing about the end of Israel's exile. Wright believes that the Jesus of history understood his own mission in these terms; whether that is so or not, Matthew certainly understood Jesus' work in that way.
} 
Rebecca, and Leah. It is sometimes suggested that each of the four women mentioned by Matthew was in some way involved in unusual or disreputable sexual activity - thus providing the background for an apologetic reading of the story of Jesus' mother Mary (Mt 1:16), who was also suspected of sexual impropriety (Mt 1:18-25). If the Abrahamic-Davidic line was carried forward to the Messiah through these women of questionable virtue, so the argument goes, then we should not be surprised if doubt attends the reputation of the Messiah's mother as well. Yet, anyone who took offence at these women and their offspring would be "depreciating what God had chosen to bless" (see Davies \& Allison 1988:171). It is by no means clear, however, that Ruth should be included in a list of women accused of sexual irregularities. Additionally, in the case of the story of David and Bathsheba, it is David who is singled out as a sinner; that is where all the emphasis is placed in the canonical narrative, as shown with particular clarity in 2 Samuel 12:1-15. The story places no blame on Bathsheba. Furthermore, we should not overlook the fact that three of these anomalous women (Tamar, Rahab, and Ruth) are heroines who are commended in the biblical stories for their daring and faithful actions (Gn 38:1-30; Jos 2:1-24, 6:22-25; Ruth passim). In other words, they are characterized in the stories not by their doubtful reputations but by their tenacious fidelity. ${ }^{7}$

More pertinent for Matthew's purposes is the fact that all four can be understood as non-Israelites. Tamar was understood in some Jewish traditions as a Canaanite or a proselyte. ${ }^{8}$ Rahab was a Canaanite, Ruth a Moabite, and Bathsheba was the wife of Uriah the Hittite. (This does not necessarily mean that she was herself a Hittite, but Matthew might have inferred that she was.) In each case, these foreigners were included within the story of Israel and indeed made part of the bloodline of David, the archetypical king of Israel. Thus, in the genealogy Matthew already hints at a major theme of his gospel: the story of Israel is open to the inclusion of Gentiles. These four women in the ancestry of the Messiah prefigure the mission to "all nations" (Mt 28:19) by demonstrating that God has woven ethnic outsiders into the story from start to finish. Matthew explains none of this, nor does he quote any of the Old Testament passages in which Tamar, Rahab, Ruth, and

\footnotetext{
${ }^{7}$ In this way, they prefigure the Canaanite woman of Matthew 15:21-28 (see Levine 2001:2241).

${ }^{8}$ Richard Bauckham (1995:313-29) shows that references to Tamar as "daughter of Aram" in Jub 41:1 and TJud 10:1 should not be understood to mean that she was an Aramaean. As Bauckham demonstrates, however, the biblical account in Genesis 38 is ambiguous on the question of her ancestry, and Philo (Virt 220-22) refers to her as a Syrian Palestinian - that is, a Canaanite - who converted to worship the one true God. The text of bSot 10 provides evidence for a rabbinic tradition that she was a proselyte.
} 
Bathsheba appear. Still, his inclusion of them in the genealogy of Jesus encourages the reader to recall their stories and ponder their significance for understanding the shape of Israel's story. They prefigure the mission to "all nations" that is announced in the Gospel's closing chapter.

\subsection{Israel typology (Mt 2:13-18)}

Another way that Matthew carries forward the story of Israel is through a typological identification of Jesus with Israel: Jesus becomes the one in whom the fate of Israel is embodied and enacted. ${ }^{9}$ The story of Israel and the story of Jesus become one and the same. In this respect, Matthew's narrative differs notably from Mark's, in whom the identification of Jesus as "Israel" plays very little, if any, role.

This motif runs throughout Matthew's Gospel, but it is most vividly expressed in his compressed account of the Holy Family's flight into Egypt and return after the death of Herod (Mt 2:13-15) - a tale unparalleled in the other Gospels. Matthew sees in this episode a figural fulfilment of Israel's sojourn in Egypt and return to the land of promise. The key prophetic text adduced in the formula quotation of Matthew 2:15 is drawn from Hosea 11:1: "When Israel was a child I loved him, and out of Egypt I called my son." This is a celebrated case in which Matthew does not follow the LXX, which reads,

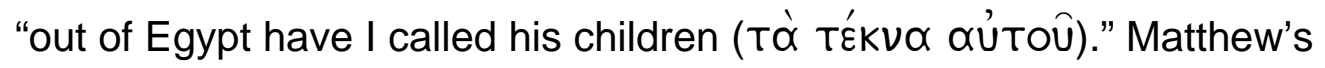
predictive Christological reading depends on a Greek text (Tòv vióv Mou) that corresponds to the MT. ${ }^{10}$ In context in Hosea, the "son" is clearly the people Israel as a whole; the sentence is not a prediction of a future Messiah but a reference to past events of the exodus. Thus, Hosea's metaphor, referring to Israel corporately as God's "son," evokes a tradition that goes all the way back to God's instructing Moses to tell Pharaoh that "Israel is my firstborn son" (Ex 4:22-23). Matthew, however, transfigures Hosea's text by seeing it as a prefiguration of an event in the life of Jesus. Matthew now sees the fate of

\footnotetext{
${ }^{9}$ This observation is also directly pertinent, of course, to the question of how Matthew uses Scripture to define the identity of Jesus. I would like to acknowledge that my reflections about Matthew's identification of Jesus with Israel have been independently reinforced by an unpublished essay by Gaylen Leverett (s a), "Jesus as Israel: A Matthean analogy."

${ }^{10}$ For purposes of the present discussion, it makes little difference whether Matthew was translating the Hebrew independently or following an extant Greek translation closer in wording to the MT. Davies and Allison (Matthew $1.262 \mathrm{n} 8$ ) mention that a scribal note in the margin of $\aleph$ ascribes Matthew's quotation to Numbers 24:8, which reads, in the LXX, "God led him out of Egypt." Given the widespread use of the oracle of Balaam as a messianic testimony (esp Nm 24:17), it is not surprising that early Christian readers, finding that the LXX of Hosea 11:1 gave no support to Matthew's citation, would be drawn to Numbers 24:8 instead. Note also that Numbers 24:7 LXX reads, "A man shall come forth out of his [Israel's] seed, and he shall rule many nations." There is no evidence, however, that Matthew was aware of any of this. The suggestion of Davies and Allison (1988:262) that Matthew's attention was drawn first to Numbers 24 and then secondarily to Hosea 11:1 is purely speculative.
} 
God's "son" Israel recapitulated in the story of God's Son, Jesus: in both cases, the son is brought out of exile in Egypt back to the land. (Does this pattern of deliverance also prefigure the story of Jesus' death and resurrection? Matthew offers no explicit indication to that effect, but the symbolic inference lies readily at hand.)

This example suggests that Matthew's formula quotations may have more narrative resonance and allusive subtlety than is often credited to them. Matthew cannot be unaware of the original contextual meaning of Hosea 11:1 as an expression of God's love for Israel - a love that persists even through Israel's subsequent unfaithfulness (Hs 11:8-9). Indeed, Matthew's use of the quotation depends upon the reader's recognition of its original sense. Note carefully: If Hosea's words were hermeneutically severed from reference to the original exodus story, the literary and theological effect of Matthew's reading would be stifled. The fulfilment of the prophet's words can be discerned only through an act of imagination that perceives the typological correspondence between the two stories of the exodus and the gospel. Through the lens of the typological imagination the two narrative patterns are projected on top of one another, so that the story of Jesus acquires the resonances of the story of Israel's deliverance. The effect of the juxtaposition is to hint that Jesus now will carry the destiny of the people Israel, and that the outcome will be the rescue and vindication of Israel, as foreshadowed in the exodus story and brought to fulfilment in the resurrection of Jesus. The prophetic text from Hosea 11:1 functions as a middle term between the two stories, providing the hermeneutical clue that the exodus story is to be read as a narrative template for God's choosing and saving his people, a template that can be applied to subsequent historical circumstances - whether God's mercy to disobedient Israel in Hosea's day or God's climactic rescue of his people Israel in the person of the Messiah Jesus. ${ }^{11}$

It is also significant that Matthew's citation of Hosea has the effect of naming Jesus as God's son in first-person divine discourse. Although the story of the miraculous conception of Jesus (Mt 1:18-25) has already disclosed to the reader that Mary's child is begotten "from the Holy Spirit," the first explicit identification of Jesus as God's "son" in Matthew's narrative is placed in the mouth of God himself, as the introduction to this formula citation emphasizes: The flight into Egypt was the fulfilment of "that which was spoken

\footnotetext{
${ }^{11}$ Davies and Allison (Matthew 1.263-264) rightly identify this figural dimension of the story and see here a connection to other ancient Jewish sources that envision a new "eschatological exodus and return to the land."
} 
by the Lord through the prophet" (Mt 2:15). ${ }^{12}$ This divine validation of Jesus' sonship anticipates the declarations of the divine voice at Jesus' baptism and transfiguration: "This is my Son, the Beloved, in whom I am well pleased" (Mt 3:17; $17: 5$ - both echoing Gn 22:2; Ps 2:7, and Is 42:1). Thus, Matthew 2:1315 accomplishes at least two purposes at once: it articulates the identity of Jesus as God's son, and it guarantees that the reader who knows the exodus tradition will understand his "sonship" precisely as a confirmation of his figural identity with Israel.

Alerted to this figural dimension of Israel's story, the reader of Matthew's Gospel may then also hear other resonances in the next brief unit of the birth narrative, the grim account of Herod's slaughter of the children of Bethlehem (Mt 2:16-18), which concludes with another formula quotation (Mt 2:17-18):

Then was fulfilled what had been spoken through the prophet Jeremiah:
A voice was heard in Ramah, wailing and loud lamentation, Rachel weeping for her children; she refused to be consoled, because they are no more.

Here it appears that the story of Israel, as Matthew carries it forward, is a story of suffering and lament. Ramah, in the book of Jeremiah, appears as a staging ground for the deportation of the Judean captives to Babylon (cf Jr 40:1). Rachel, the wife of Jacob/Israel and therefore the figurative mother of the people as a whole,$^{13}$ mourns proleptically from the past over the exile and, by implication, over the repeating pattern of violence against God's chosen. Herod's murder of the innocents takes its place alongside Pharaoh's decree against the Hebrew boy babies (Ex 1:15-22) and the defeat and exile of Judah in Jeremiah's time. Yet, recalling the latter story of exile, we may also hear an echo from the conclusion of Matthew's genealogy: "from the deportation to Babylon to the Messiah, fourteen generations." Indeed, to recall

\footnotetext{
12 Thus, this citation reinforces the earlier quotation of Isaiah 7:14 as a word spoken "by the Lord" identifying Jesus as a "son" through whom God is present to the people (Mt 1:21-23). These are the only two Matthean fulfillment quotations in which the words úmo kupíou appear in the citation formula.

${ }^{13}$ Rightly noted by Christine Ritter (2003:121).
} 
Jeremiah's prophecy is necessarily to recall also its wider context (Jr 31:15$17)^{14}$

Thus says the LORD:

A voice is heard in Ramah, lamentation and bitter weeping.

Rachel is weeping for her children; she refuses to be comforted for her children, because they are no more.

Thus says the LORD:

Keep your voice from weeping, and your eyes from tears; for there is a reward for your work, says the LORD:

they shall come back from the land of the enemy; there is hope for your future, says the LORD:

your children shall come back to their own country.

Jeremiah's image of Rachel weeping is a prelude to his bold prophecy of hope for the end of exile. Indeed, Jeremiah's oracle continues with an account of God's undying love for "Ephraim my dear son", promising that "I will surely have mercy on him" (Jr 31:18-20). That is the reason why there is hope for the future: violence and exile do not have the final word, for God's love for Israel will prevail and bring about restoration.

Surely it is not merely coincidental that in consecutive formula quotations (Mt 2:15, 2:17-18) Matthew has linked these two very similar passages from Hosea 11:1-11 and Jeremiah 31:15-20. Both prophetic texts speak of the exile and suffering of an unfaithful people, and both declare that God will reach out in mercy and bring the people back from exile. By evoking these prophecies in the infancy narrative, Matthew connects both the history and the future destiny of Israel to the figure of Jesus, and he hints that in Jesus the restoration of Israel is at hand. This suggests that Matthew is not merely looking for random Old Testament proof texts that Jesus might somehow fulfil; rather, he is thinking about the shape of Israel's story and linking Jesus' life with key passages that promise God's unbreakable redemptive love for his people. ${ }^{15}$ That is why Matthew comments on Herod's slaughter of children by selecting a citation from the same chapter in Jeremiah

\footnotetext{
${ }^{14}$ Ritter (2003:122-23) cautiously puts forward this suggestion.

${ }^{15}$ What I am claiming here about Matthew is formally analogous to the finding of recent studies of Paul's readings of Israel's Scripture: Matthew, like Paul, sees a coherent plot in the Old Testament texts that he cites. For Paul, see J Ross Wagner's (2002), Heralds of salvation: Paul and Isaiah "In concert" in Romans 9-11; and Francis Watson's (2004), Paul and the hermeneutics of faith.
} 
that also promises "a new covenant with the house of Israel and the house of Judah" (Jr 31:31): Matthew's reference to Rachel works as a metaleptic trope, recalling the wider context of Jeremiah's prophecy. ${ }^{16}$ Herod's murderous acts, then, function within Matthew's tale as a metaphor for all the history of Israel's grief and exile. Yet even in the dark moment of Rachel's grief, the echo of Jeremiah 31 offers comfort, beckoning God's people to lean forward into the hope of the days that are surely coming when God will have mercy, bring back the exiles, and write the Law on their hearts.

\subsection{Jesus demands a higher righteousness that includes obedience to Torah (5:17-48)}

Jeremiah's image of the Law written on the hearts of the people (Jr 31:33) an image that Matthew never employs directly - anticipates Matthew's treatment of the demands of Torah. Distinctively among the evangelists, Matthew insists that the commandments of the Law remain fully in force (Mt 5:17-19). Jesus, rather than abolishing the Law, calls his followers to a higher righteousness that exceeds, rather than negates, the righteousness of the scribes and Pharisees (Mt 5:20). (There is no trace of such an idea in Mark.) How does the righteousness for which Jesus calls exceed scribal and pharisaical righteousness? According to the programmatic antitheses of Matthew 5:21-48, the higher righteousness is a matter not only of outward actions, but of inner dispositions and motivations. It is not sufficient, for example, to refrain from murder; the real problem is anger in one's heart. Jesus instructs his disciples to recognize such inner malformations of the self, to seek reconciliation with their brothers and sisters (Mt 5:23-24), and to pursue the goal of perfection (Mt 5:48). Such radical obedience is possible only through a transformation of character, enabling not merely outward obedience to the Law's requirements but also an inner obedience from the heart. In light of such a vision Jesus summons his disciples to renounce not only murder but also anger, not only adultery but also lust (Mt 5:21-30). ${ }^{17}$

Thus, for Matthew the story of Israel is carried forward by a community of discipleship, as envisioned in the Sermon on the Mount, a community that embodies radical obedience to the Torah as authoritatively interpreted by Jesus. Apart from such obedience, confessional orthodoxy is useless: "Not everyone who says to me 'Lord, Lord,' will enter into the kingdom of heaven,

\footnotetext{
${ }^{16}$ In brief, "metalepsis," as analyzed by John Hollander, is a literary device that links two texts, $A$ and $B$, in such a way that a fragmentary citation of $A$ in $B$ requires the reader to recall and supply elements of text $A$ that are not explicitly cited. For fuller discussion of this literary device, see R B Hays (1989), Echoes of scripture in the letters of Paul.

${ }^{17}$ For a discussion of transformation of the heart in Matthew, see Richard B Hays (1996:9699).
} 
but only the one who does the will of my father in heaven" (Mt 7:21). Matthew's vision of community is, if we may put it this way, thoroughly Deuteronomic. He would applaud the admonition of Deuteronomy 30:11: "Surely, this commandment that I am commanding you this day is not too hard for you, nor is it too far away." One sign of this Deuteronomic orientation is that Jesus answers the devil's temptations in the wilderness through direct citations of Deuteronomy (Mt 4:1-11, in which Jesus quotes Dt 8:3, 6:16, and $6: 13)$ - another indication, by the way, that Matthew's Jesus assumes the role of obedient Israel.

That Matthew seriously believes that not a jot or tittle shall perish from the Law (Mt 5:18) is nowhere made clearer than in Jesus' scathing attack on the scribes and Pharisees in chapter 23. Matthew's Jesus offers a hermeneutical refocusing of the Law in terms of justice, mercy, and faith, but he takes care to specify that these virtues neither replace nor pre-empt the demand for meticulous observance of Torah's commandments: "Woe to you, scribes and Pharisees, hypocrites! For you give a tenth of your spices - mint, dill and cummin, and have neglected the weightier matters of the Law: justice and mercy and faith. It is these you ought to have practiced without neglecting the others" (Mt 23:23). Even in this fierce polemic against the scribes and Pharisees, Jesus nonetheless instructs his disciples and the crowds to follow whatever they teach, abiding by what they say but not following the example of what they do; the major indictment against them is that they do not practice what they teach (Mt 23:1-3). Thus, Matthew is a good holiness theologian: he teaches that Jesus' followers must carry forward the story of Israel within a community of great moral stringency, in strict obedience to the commandments of Torah. ${ }^{18}$

And yet, for all his affirmation of the Torah, Matthew's account of what obedience to Torah actually entails has some distinctive features over against other contemporary forms of halakhah. Surprisingly, Matthew is silent about circumcision, and his position on purity laws is emphatically non-pharisaic, as shown by his account of Jesus' rejection of oral Torah ("Why do you break the commandment of God for the sake of your tradition?" - Mt 15:3), and his casual stance on food and purity laws ("It is not what goes into the mouth that defiles a person, but it is what comes out of the mouth that defiles" - Mt

\footnotetext{
${ }^{18}$ This feature of Matthew's gospel has led some interpreters to Matthew represents a community that has remained fully within the bounds of first-century Judaism, that Matthew represents not "Jewish Christianity" but "Christian Judaism" (see especially David C Sim [1998], The Gospel of Matthew and Christian Judaism: The history and social setting of the Matthean community). For the opposing view that Matthew's vision places him outside the perimeter of Jewish belief and practice, see Stanton (1992), Gospel for a new people and John K Riches (2000), Conflicting mythologies: Identity formation in the Gospels of Mark and Matthew, pp 316-324.
} 
15:11). Again, here, we see the concern with purity of heart as the key issue for Matthew: "... what comes out of mouth proceeds from the heart, and this is what defiles" (Mt 15:18). ${ }^{19}$ How are such teachings to be squared with the claim that Jesus has come not to abolish the Torah but to fulfil it? Clearly, Matthew is operating with a flexible theological notion of "fulfilment" that is not rigidly identified with literal performance of all of the Law's commandments. Jesus' fulfilment of the Law is partly related to his own embodied enactment of its meaning (as in the fulfilment quotations), but it is also connected to a particular hermeneutical construal of Torah.

This comes clear especially in Matthew's handling of the lawyer's question about the greatest commandment (Mt 22:34-40). In Mark 12:28-34, the questioning scribe affirms Jesus' answer and then gives his own commentary that links the two great commandments to other confirming scriptural texts, thereby earning Jesus' blessing. In contrast to Mark's dramatic complexity, we find in Matthew a straightforward pronouncement story: The lawyer asks, Jesus answers. His answer, of course, is a fusion of the Shema (Dt 6:5) and Leviticus 19:18, commanding love of God and of neighbor. In Matthew's narrative, this comes as no great surprise to the reader, for three chapters earlier, in his response to the rich man's question about what he must do to gain eternal life, Jesus has already linked Leviticus 19:18 to the ten commandments (Mt 19:16-19). In Matthew 22, however, Jesus' quotation of the two great commandments is not yet the final punch line of the pronouncement story. The climax of the pronouncement in Matthew is this: "On these two commandments hang all the law and the prophets." These two commandments, in other words, are not merely the greatest or the most important; rather, they have a systemic, structural role. All of the other commandments in Torah are suspended from these two pillars. It is not a matter of priority on a list, but of weight bearing. This claim is fully consistent with Matthew's insistence that in Jesus' teaching the Law remains in force. Yet, at the same time, the passage inescapably proposes a particular hermeneutical reconfiguration of Torah, one in which love becomes the most determinative requirement. As the history of interpretation amply demonstrates, where such a hermeneutical reconfiguration takes place, the other commandments tend over time to recede in importance. Thus, in Matthew 22:34-40, we see the forces at work that produce - perhaps even contrary to Matthew's own intention - a reshaping of Torah into a new framework.

\footnotetext{
${ }^{19}$ Matthew, with characteristic diplomacy, deletes Mark 7:19b, "declaring all foods clean." His concern is not to press an ideology of rejecting Jewish food laws but rather to shift the emphasis to purity of heart as the Torah's chief concern.
} 


\subsection{The hermeneutic of mercy}

Further, Matthew's strict exhortation to Torah-obedience is modulated into another key by his equally firm insistence that the obedient community of disciples must also be a community animated by mercy, love, and forgiveness. The moral rigor of the Sermon on the Mount, to be rightly understood and practiced, must be framed both by the recognition that we are weak and fallible, and by the willingness to forgive one another as freely as God forgives us, even seventy times seven (Mt 18:21-22). This theme appears repeatedly in the Gospel of Matthew - for example in Jesus' instruction about how to pray (Mt 6:9-15) and in the parable of the unforgiving servant (Mt 18:23-35), which climaxes in the lord's rebuke to his hard-hearted servant: "You wicked slave! I forgave you all that debt because you pleaded with me. Should you not have had mercy on your fellow slave, as I had mercy on you?" (Mt 18:32-33). This key Matthean motif of mercy is highlighted particularly through the use of Scripture. In two places Matthew tellingly inserts references to Hosea 6:6 into narrative material taken over from Mark, in order to emphasize the hermeneutical primacy of mercy.

The first instance appears in Matthew's account of Jesus' controversy with the Pharisees over his practice of eating with tax collectors and sinners (Mt 9:9-13). Matthew follows Mark's text closely through most of the passage $;^{20}$ in Jesus' climactic pronouncement Matthew reproduces Mark 10:17 almost word for word except that he adds the crucial citation of Hosea: "Those who are well have no need of a physician, but those who are sick. Go and learn what this means, 'I desire mercy, not sacrifice.' For I have come to call not the righteous but sinners" (Mt 9:12-13).

In the Markan form of the story, Jesus responds to the carping of his critics with a forceful aphorism that justifies his association with sinners on the grounds that he must go to those in need of healing and correction; the Markan saying offers no biblical warrant for this claim. Matthew, however, imbeds within the aphorism a scriptural quotation that produces further ripples of signification. The Pharisees, who protest Jesus' association with sinners, are chided for their failure to grasp the intention of God. Jesus directs them to a particular prophetic text for remedial education: if they learn what Hosea means, they will understand that God is a God of mercy (חסד) who desires to bring back the erring, not to condemn them, not even to compel them to offer the proper sacrifice.

\footnotetext{
${ }^{20}$ The most significant changes in Matthew 9:9-12 are in the name of the tax collector whom Jesus summons to follow him (Mark calls him "Levi", while Matthew calls him "Matthew") and in Matthew's correction of the odd Markan phrase "the scribes of the Pharisees".
} 
Once again, as in the formula quotations in the birth narrative, Matthew has focused on a prophetic text (Hs 6) that describes the plight of exilic Israel and figures forth the gracious mercy of God. (This suggests inter alia that Jesus' mission to the tax collectors and sinners aims not merely at individual moral reform but at the restoration of the nation.) Furthermore, it is hardly accidental that Matthew links Jesus' saying about the need for a physician to a prophetic passage that depicts Ephraim and Judah as crying out, "Come, let us return to the Lord; for it is he who has torn, and he will heal us" (Hs 6:1; cf Hs 7:1). ${ }^{21}$ The passage deals with the hope that God will bring healing to Israel, a torn and broken nation. Thus, if the Pharisees go to learn what Hosea 6:6 means, they will have to read more than one verse. If they read the wider context, they will find there, in the midst of a judgment oracle against the people, a call for repentance and a portrayal of a merciful God who wants his people to show mercy, not contempt, to those who have gone astray.

Matthew's second pointer to Hosea 6:6 appear three chapters later, in the controversy story about plucking grain on the Sabbath (Mt 12:1-8). Once again Matthew follows Mark's narrative framework very closely ${ }^{22}$ but alters the content of Jesus' concluding pronouncement. This time, the alterations are quite substantial. ${ }^{23}$ To examine these in detail would require a lengthy excursus; however, the salient point is that Matthew once again inserts a reference to Hosea 6:6: "But if you had known what this means, I desire mercy and not sacrifice, you would not have condemned the guiltless." Here the application of the Hosea citation to the situation of the grain-plucking disciples is less than obvious. It appears that "mercy" and "sacrifice" are used metonymically. They stand for, respectively, a form of piety that focuses on God's compassion towards human needs and a form of piety that focuses on ritual observances. The Pharisees are at fault because they demand

\footnotetext{
${ }^{21}$ Modern critical readers may find in Hosea 6:1-3 a depiction of an insincere or inadequate repentance, but it is doubtful that the text would have been so understood by ancient readers. Certainly Matthew offers no hint of understanding the passage that way.

${ }^{22}$ Matthew corrects Mark by omitting the erroneous phrase "when Abiathar was high priest" (Mk 2:26). This is one of many editorial nuances that show how carefully Matthew was reading his sources. He does not merely take over Scriptural references from Mark; he crosschecks them, either directly against the OT text or against his comprehensive knowledge of that text.

${ }^{23}$ Matthew deletes the saying that "the sabbath was made for man, and not man for the sabbath"; in its place, he adds vv 6-7, which assert a precedent for the disciples' grainplucking actions in the labors of the priests in the temple on the sabbath.
} 
punctilious observance of the Law at the expense of basic human need, represented by the disciples' hunger. ${ }^{24}$

In both of these passages, Hosea 6:6, with its emphasis on mercy, is put forward as a hermeneutical lens through which the entire Torah is to be interpreted. The Pharisees go astray in their understanding of the Law because they fail to realize that its central aim, as disclosed in Hosea, is mercy. Alongside these passages should be placed the beatitude, "Blessed are the merciful, for they shall receive mercy" (Mt 5:7), and Jesus' pronouncement, noted above, that "the weightier matters of the Law" are "justice and mercy and faith" (Mt 23:23). Clearly, for Matthew, mercy is a central theme. The important thing to recognize, in all these passages, is that the quality of mercy is not set in opposition to the Torah; rather, Matthew's Jesus discerns within Scripture itself the hermeneutical principle - expressed epigrammatically in Hosea 6:6 - that all the commandments are to be interpreted in such a way as to engender and promote the practice of mercy among God's people.

It may appear that there is a certain hermeneutical slippage here: can the meaning of the Torah (conceived as the books of the Pentateuch) be determined by a citation from a prophetic book? Should a distinction be made between Torah and the Prophets? ${ }^{25}$ Can Hosea 6 really be used as a lens to determine what Torah requires? The point is near the heart of Matthew's controversy with the Judaism of his day. ${ }^{26}$ It seems clear that Matthew's hermeneutical privileging of the Prophets is precisely one of the key ways that he reconfigures Torah. Thus, for Matthew, the story of Israel is carried forward through a particular, prophetically shaped, interpretation of Torah within a community called to embody the mercy of God.

\footnotetext{
${ }^{24}$ As the capstone of this unit, Matthew retains Mark's declaration that: "The Son of Man is Lord of the sabbath" (Mk 2:28/Mt 12:8). While Mark 2:28 (in which the declaration is

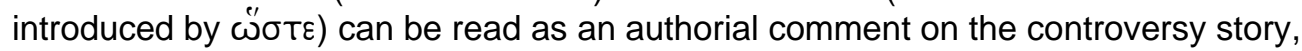
Matthew's editing of the saying almost surely should be understood as placing this bold claim on the lips of Jesus himself.

${ }^{25}$ Matthew's apparent conflation of Law and Prophets is anticipated by Paul in 1 Corinthians

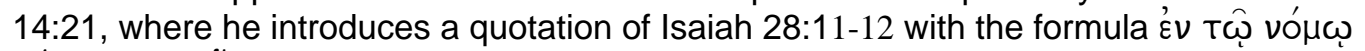

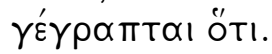

${ }^{26}$ An intriguing parallel to these Matthean passages may be found in the later Abot de Rabbi Nathan 4: "Once as Rabbi Johanan ben Zakkai was coming forth from Jerusalem, Rabbi Joshua followed after him and beheld the Temple in ruins. 'Woe unto us!' Rabbi Joshua cried, 'that this, the place where the iniquities of Israel were atoned for, is laid waste!' 'My son', Rabbi Johanan said to him, 'be not grieved; we have another atonement as effective as this. And what is it? It is acts of loving-kindness, as it is said, For I desire mercy and not sacrifice' (Hs 6:6)" (cited according to the translation of Judah Goldin [1955:34], The Fathers according to Rabbi Nathan).
} 


\subsection{Light to the Gentiles}

Finally, Matthew's reading of Scripture opens the narrative of God's mercy to embrace the Gentiles. Indeed, he intimates that it has always been Israel's special destiny to bear God's light to the nations, and that this destiny has now come to fruition in the mission that Jesus has initiated. The Isaianic eschatological vision of the nations bringing tribute and coming to worship the God of Israel is adumbrated in Matthew's story of the magi, who say to Herod, "We have seen his star at its rising, and we have come to worship him" (Mt 2:2). This artful story - without the quotation of a proof text about Gentiles already prefigures Jesus' sovereignty over all nations, which is explicitly declared in the conclusion of Matthew's narrative (Mt 28:16-20). The church's subsequent interpretative tradition has well understood this figurative dimension of Matthew's story, as shown in the traditional lectionary readings for Epiphany, which connect Matthew 2:1-12 with Isaiah 60:1-6 (see especially Is 60:3: "Nations shall come to your light, and kings to the brightness of your dawn.").

Matthew's interest in the Gentile mission is foreshadowed once again in the formula quotation that accompanies the beginning of Jesus' Galilean ministry (Mt 4:12-17):

Now when Jesus heard that John had been arrested, he withdrew to Galilee. He left Nazareth and made his home in Capernaum by the sea, in the territory of Zebulon and Naphtali, so that what had been spoken through the prophet Isaiah might be fulfilled:

"Land of Zebulon, land of Naphtali, on the road by the sea, across the Jordan, Galilee of the Gentiles - the people who sat in darkness have seen a great light, and for those who sat in the region and shadow of death light has dawned."

From that time Jesus began to proclaim, "Repent, for the kingdom of heaven has come near."

At the most literal level of discourse, this citation simply functions as a proof text explaining why Jesus took up residence in Capernaum. To read the citation only at this level, however, is to miss the figurative implications of the passage. The quotation of Isaiah 9:1-2 (=8:23-9:1 MT), read metaphorically, suggests that the scope of Jesus' revelatory work will be wider than one limited geographical area. In the original historical context of Isaiah 8:23-9:1, "the people who walked ${ }^{27}$ in darkness" were the Israelites living under

\footnotetext{
${ }^{27}$ Thus MT. The LXX translates with the present participle mopєuó $\mu \varepsilon v o 5$. On Matthew's

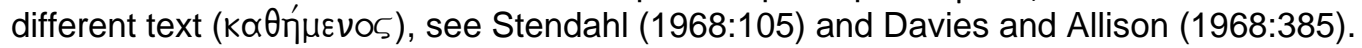


Assyrian rule. Carrying this historical sense forward into the first century CE, it would be possible to read Matthew 4:12-17 as referring simply to Jesus' announcement of God's liberating kingdom for the Jewish residents of this area of Galilee. Narratively, this makes sense on a first reading, and it is consistent with Matthew's portrayal of Jesus' ministry as restricted to "the lost sheep of the house of Israel" (Mt 10:5-6). Several features of the passage, however, lend themselves to the suggestion that Matthew also sees here a prefiguration of the extension of the gospel to the Gentiles. The most obvious indicator is the phrase "Galilee of the Gentiles" as a description of the place where the light appears. ${ }^{28}$ Equally significant, however, is the reference to the

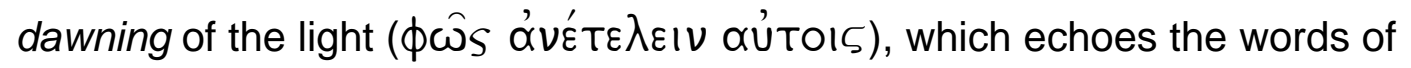

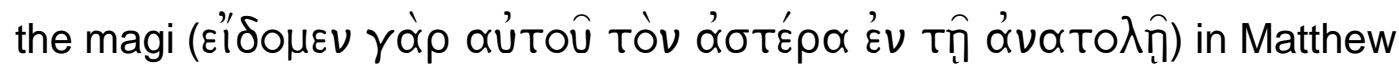
2:2. As we have seen, Matthew's narrative has already associated the image of a rising light with the theme of revelation to the Gentiles (Mt 2:1-12). Further, the description of the sphere of the people's confinement as "the region and shadow of death" (this time following the LXX of Is 9:1) lends itself readily to metaphorical reinterpretation in a post-resurrection situation: the light revealed in Jesus overcomes the power of death. Thus, the saving power of Jesus is not limited to providing a solution for Israel's national predicament; it addresses the more fundamental human problem of bondage to death.

In consideration of all these factors, Matthew's narrative leads readers to see the beginning of Jesus' ministry as the dawning of light for the whole world, including Gentiles. ${ }^{29}$ The summary of Davies and Allison precisely catches this metaphorical import: "[Matthew] wants a scriptural text linking the Messiah and the Gentiles. And he wants this in 4:14-16 so that the end will be foreshadowed in the beginning: although Jesus must minister only to the lost sheep of the house of Israel, the kingdom will eventually embrace the Gentiles."30

This reading of Matthew 4:12-17 is confirmed by Matthew's handling of another passage from Isaiah near the midpoint of his narrative (Mt 12:15b-21, quoting Is 42:1-4):

\footnotetext{
${ }^{28}$ This expression does not signify that Galilee was predominantly Gentile in population and culture in Matthew's time. On this question, see Mark A Chancey (2002), The myth of a gentile Galilee.

${ }^{29}$ Interestingly, Luz (1989:195) cites Christian traditions of interpretation that parse Isaiah 9:1 as referring separately in its two clauses to Jews (the people sitting in darkness) and to Gentiles (those who are sitting in the land and shadow of death). This is a distinctly different approach from the reading I have offered here, in which both phrases designate the original Jewish beneficiaries of Jesus' revelation and, at the same time, both phrases metaphorically point forward to the inclusion of Gentile converts.
}

${ }^{30}$ Davies and Allison (1988:385). 
Many crowds followed him, and he cured all of them, and he ordered them not to make him known. This was to fulfil what had been spoken through the prophet Isaiah:

"Here is my servant, whom I have chosen, my beloved, with whom my soul is well pleased.

I will put my Spirit upon him, and he will proclaim justice to the Gentiles.

He will not wrangle or cry aloud, nor will anyone hear his voice in the streets.

He will not break a bruised reed

or quench a smoldering wick

until he brings justice to victory.

And in his name the Gentiles will hope."

Once again, Matthew has drawn the reader's attention to a prophetic text that proclaims the extension of salvation to the Gentiles. As commentators have often remarked, Isaiah 42:1-4 is an odd proof text for Jesus' ordering the crowds not to make him known, and it is equally odd that Matthew quotes much more of the text than he needs to make his point. This surplus of cited material suggests that Matthew is once again seeking to draw the reader's attention to the broader literary and theological context in Isaiah. His concern here is not only to provide scriptural warrant for the Markan secrecy motif but also to hint that Jesus' healing activity prefigures the Isaian Servant's mission of bringing healing and justice to the nations. ${ }^{31}$

The development of this theme comes to its climax in the resurrection appearance story that concludes Matthew's narrative (Mt 28:16-20). Matthew brings his Gospel to its close with Jesus' charge that his disciples should go

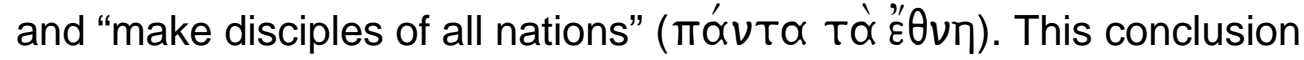
functions as both warrant and motive for a mission that carries the preaching of the gospel beyond the boundaries, both geographic and ethnic, of Israel. It is, in a very real sense, the telos towards which Matthew's whole narrative has been driving. The last sentence of the Gospel, in which Jesus promises his continuing presence with the disciples in their work of baptizing and teaching the nations to obey Jesus' commandments, functions as reassurance and support for this mission - no doubt a highly controversial mission in Jewish communities in Matthew's time. All of this is widely recognized.

Perhaps less often recognized, however, is the crucial point that Jesus' words in this concluding mission charge echo the description of the everlasting authority over all nations given to the "one like a Son of Man" in Daniel 7:14: "To him was given dominion and glory and kingship, that all

\footnotetext{
${ }^{31}$ For a thorough and illuminating study of the passage, see Richard Beaton (2002), Isaiah's Christ in Matthew's Gospel.
} 
peoples, nations, and languages should serve him. His dominion is an everlasting dominion that shall not pass away, and his kingship is one that shall never be destroyed." The connection to Matthew 28:18-20 is even

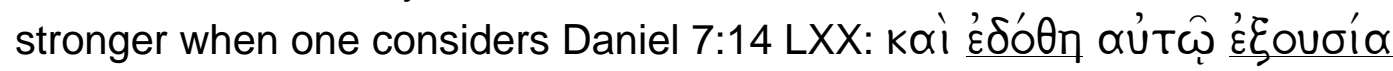

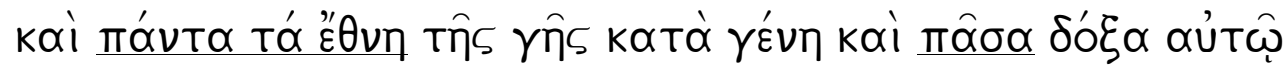

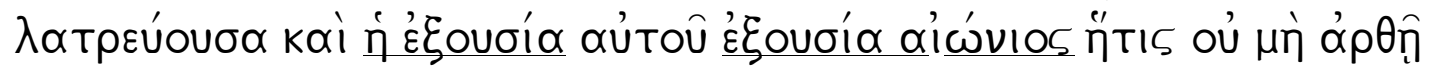

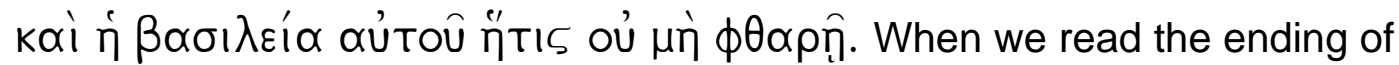
Matthew against this background, we recognize that Matthew is portraying the risen Jesus as the triumphant Son of Man figure - representing Israel - who

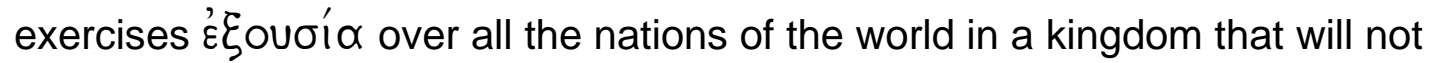
pass away. ${ }^{32}$ Thus is fulfilled Jesus' declaration before the high priest during

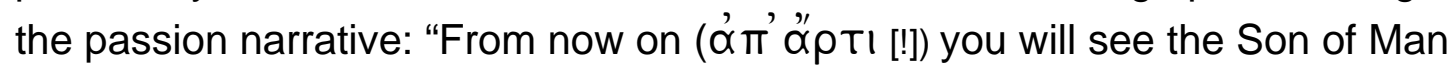
seated at the right hand of Power and coming on the clouds of heaven" (Mt 26:64, again echoing Dn 7:13-14). Thus - and here is the crucial point for our present concerns - the disciples' mission to the Gentiles constitutes the fulfillment of Israel's story. Daniel's vision of Israel at last vindicated and ruling over the Gentile nations is to be enacted precisely through the disciples' work of preaching and teaching. Their mission will enact the triumph of Israel's God by extending his sovereignty over all the nations on earth. Integral to Matthew's vision, however, is his insistence that the sovereignty of God over the nations becomes effectual through non-violent means. The nations are "conquered," as it were, through baptism into the name of the Father and of the Son and of the Holy Spirit and through their instruction to obey the teachings of a master who has insisted that the meaning of the Torah is summed up in acts of love and mercy.

\section{CONCLUSION: HOW DOES MATTHEW'S READING OF SCRIPTURE RESHAPE TORAH?}

It is time to summarize our findings. We began our discussion with Rowan Williams' (1998) proposal that the death and resurrection of Jesus led to a prolonged process of "reorganization of religious language," a process to

\footnotetext{
${ }^{32}$ This reading is considered but rejected by Terence L Donaldson (1985:176-178): “... while Matthew may have made some use of Danielic language, he did not intend his closing pericope to be a fulfillment of Dn 7:13f, so that the Daniel passage was not the controlling factor in its construction." So while Dn 7.13f may have had some influence on Matthew's choice of vocabulary in 28.16-20, it is of no real help in discovering the theological core of the passage. And what is true of Dn 7.13 is true of other suggested Old Testament texts as well. No single Old Testament passage has yet been found which provides a unifying principle for all features of 28.16-20." This passage, published almost twenty years ago, interestingly illustrates the distance our discipline has moved in the intervening time. Methodologically, Donaldson is looking for a source that explains or controls the Matthean passage. But an intertextual methodology asks the very different question of how Matthew is creatively reconfiguring the Old Testament language, and what effects the reconfiguration achieve.
} 
which the New Testament documents are our earliest witnesses. If anything, "reorganization" is too modest a word to describe Matthew's engagement with Israel's Scripture. We might more accurately speak of a "transfiguration", with emphasis on the figural dimension of Matthew's interpretative vision. ${ }^{33}$ The present essay has explored some of the ways in which Matthew's reading of Scripture carries forward the story of Israel, with particular attention to the transformations of Torah performed by Matthew's text. What sort of shape is given to Israel's Scripture by Matthew's interpretations? Our findings may be summarized under four headings.

- $\quad$ The narrative shape of Scripture

Matthew reads Israel's Scripture, in the first instance, not chiefly as a collection of rules and commandments, but as a story that outlines a broad arc of God's dealings with Israel. It is a story whose plot may be summed up in the following narrative sequence: election, kingship, sin, exile, and messianic salvation. This is precisely the plot sketched in the opening genealogy (see par 2.1, above) and in the metaphorically prefigurative scripture citations in the birth and infancy narrative (par 2.2). This sequence creates the frame of reference within which the reader is then to interpret everything that follows in Matthew's story of Jesus. Even Matthew's predilection for reading prophetic texts as predictive oracles derives its theological intelligibility from his conviction that all of Scripture is a great coherent story in which the elements of Israel's past point towards a messianic consummation, in which God will at last be present with his people (cf Mt 1:21-23, 28:20). The hermeneutically reconfigured Scripture remains for Matthew a constitutive intertext, a Grundgeschichte that serves as the primary matrix for the story of Jesus.

- $\quad$ Scripture as summons to transformation of heart and radical obedience Matthew's readers find themselves called into a community of rigorous, demanding discipleship, living under the radical interpretation of the Law given by Jesus. They are addressed as a city set on a hill, meant to exemplify in their life together the meaning of radical obedience. In this respect, Matthew stands very close indeed to the pharisaic Judaism that is the target of so much of his polemic. The thing that sets Matthew's program apart from that of his Jewish contemporaries is not only the specific halakhic norms established by Jesus' teachings (e g,

\footnotetext{
${ }^{33}$ Matthew is a "strong misreader" in Harold Bloom's (1973:30) sense: a later reader who appropriates earlier texts in the service of a new vision: "Poetic influence ... always precedes by a misreading of the prior poet, an act of creative correction that is actually and necessarily a misinterpretation."
} 
on divorce or swearing oaths or the ethics of retaliation) but, even more fundamentally, his distinctive emphasis on the importance of inner transformation of motivations (see par 2.3 above). The Torah is reconfigured into a call for transformation of the heart. Only in this way can the righteousness of Jesus' disciples exceed that of the scribes and Pharisees.

\section{- $\quad$ Scripture as a call for mercy}

The call for radical obedience is given a distinctive spin by Matthew's emphasis on mercy as the hermeneutical key to the whole Law (see par 2.4 above). While insisting that the Law's specific commandments remain in force (Mt 5:17-20, 23:1-3, 23:23), Matthew foregrounds mercy and forgiveness as the heart of the Law's message. There remains an inevitable tension between these elements in Matthew's thought - not a contradiction, but a contrast in emphasis and sensibility. At the end of the day, if the call for rigorous obedience seems to clash sometimes with the call for forgiveness of sinners, how is the tension to be resolved? Matthew provides no systematic solution, but the tendency of his hermeneutical strategy is to valorize mercy (or, as in Mt 22:34-40, love) as the deepest reality that provides the critical framework within which particular commandments are to be interpreted. Once again, here we find a significant reconfiguration of Torah, in contrast to other Jewish construals of Matthew's day.

- $\quad$ Scripture as context for mission to the nations

Matthew narrates a vision of the followers of Jesus as a community that is both loving and radically obedient to Jesus' reconfigured Torah. One of the key purposes for the existence of such a community in the world is to bring Gentiles to the light, so that they too can become disciples. In the overall context of Matthew's narrative, Jesus' exhortation in the Sermon on the Mount to "let your light shine before [others], so that they may see your good works and give glory to your Father in heaven" (Mt 5:16) prefigures the "Great Commission" with which the Gospel ends (Mt 28:18-20). Thus, the outsiders who are to see the light surely must include those Gentiles who previously sat in darkness (see par 2.5). The disciples' vocation to show this light is nothing other than an extension and fulfilment of the charge given by God to Israel in the prophecy of Isaiah: "I will give you as a light to the nations, that my salvation may reach to the end of the earth" (Is 49:6). Further, as we have seen, by carrying out this mission the disciples will effect the 


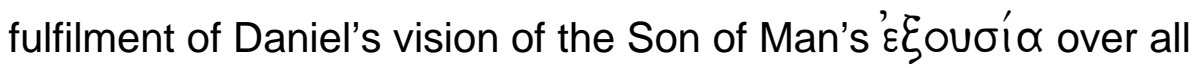
nations. Thus, Matthew's reconfiguration of Israel's Scripture as a manifesto for mission provides the final, eschatological element in the narrative reading of Scripture described in point 1 above. By making disciples of all nations, the followers of Jesus draw them into the final chapter of the story of Israel, a chapter in which God's people are sustained and guided by the presence of the risen Son of Man, until the end of the age.

All four of these elements are, arguably, organic developments of first-century Jewish thought and practice. Taken together, however, they constitute a striking reconfiguration of Israel's Scripture, particularly when we recognize that this hermeneutical transformation depends at every point on Matthew's insistence that it is the singular authority of the one man Jesus, Emmanuel, that generates, embodies, and justifies these transfigurations of the tradition.

\section{Works consulted}

Alkier, S 2002. Zeichen der Erinnerung: Die Genealogie in Mt 1 als intertextuelle Disposition. Paper presented at the Gospel of Matthew Seminar, Studiorum Novi Testamenti Societas, $56^{\text {th }}$ General Meeting, Durham, England.

Allison, D C (Jr) 1993. The new Moses: A Matthean typology. Minneapolis, MN: Fortress.

Bauckham, R 1995. Tamar's ancestry and Rahab's marriage: Two problems in the Matthean genealogy. NovT 37, 313-29

Beaton, R 2002. Isaiah's Christ in Matthew's Gospel. Cambridge: Cambridge University Press. (SNTSMS 123.)

Bloom, H 1973. The anxiety of influence. New York: Oxford University Press.

Brawley, $R$ L 2004. Evocative allusions in Matthew: Matthew 5:5 as a test case, in Ringe, S H \& Kim H C P (eds), Literary encounters with the reign of God, 12748. New York: T \& T Clark.

Chancey, M A 2002. The myth of a gentile Galilee. Cambridge: Cambridge University Press. (SNTSMS 118.)

Davies W D \& Allison, D C 1988. The Gospel according to Saint Matthew, Vol 1. Edinburgh: T \& T Clark.

Donaldson, T L 1985. Jesus on the mountain: A study in Matthean theology. Sheffield: Sheffield University Press. (JSNTS 8.)

Goldin, J 1955. The fathers according to Rabbi Nathan. New Haven, CT: Yale University Press. (Yale Judaica Series 10.)

Hays, R B 1989. Echoes of scripture in the letters of Paul. New Haven, CT: Yale University Press.

Hays, R B 1996. The moral vision of the New Testament: Community, cross, new creation. San Francisco, CA: HarperSanFrancisco.

Leverett, G s a. Jesus as Israel: A Matthean analogy. An unpublished essay. 
Levine, A-J 2001. Matthew's advice to a divided readership, in Aune D E (ed), The Gospel of Matthew in current study, 22-41. Grand Rapids, MI: Eerdmans.

Luz, U 1989. Matthew 1-7: A commentary. Edinburgh: T \& T Clark.

Menken, M J J 2004. Matthew's Bible: The Old Testament text of the evangelist. Leuven: Leuven University Press. (BETL 173.)

Minear, P S 2000. The Good News according to Matthew: A training manual for prophets. St Louis, MO: Chalice.

Overman, J A 1990. Mathew's Gospel and formative Judaism: The social world of the Matthean community. Minneapolis, MN: Fortress.

Overman, J A 1996. Church and community in crisis: The Gospel according to Matthew. Valley Forge, PA: Trinity Press International.

Repschinski, B 2004. "For He will save his people from their sins" (Mt 1:21): A Christology for Christian Jews. Paper presented at the Gospel of Matthew Seminar, Studiorum Novi Testamenti Societas, $58^{\text {th }}$ General Meeting, Barcelona, Spain.

Philo. De Virtutibus.

Riches, J K 2000. Conflicting mythologies: Identity formation in the Gospels of Mark and Matthew. Edinburgh: T \& T Clark. (SNTW.)

Ritter, C 2003. Rachels Klage im antiken Judentum und frühen Christentum. Leiden: Brill. (AGJU 52.)

Prabhu, G M S 1976. The formula quotations in the infancy narrative of Matthew. Rome: Biblical Institute. (An Bib 63.)

Saldarini, A J 1994. Matthew's Jewish-Christian community. Chicago, IL: University of Chicago Press.

Senior, D 1997. The lure of the formula quotations: Re-assessing Matthew's use of the Old Testament with the passion narrative as a test case, in Tuckett C M (ed), The Scriptures in the Gospels, 89-115. Leuven: Leuven University Press. (BETL 131.)

Sim, D C 1998. The Gospel of Matthew and Christian Judaism: The history and social setting of the Matthean community. Edinburgh: T \& T Clark. (SNTW.)

Stanton, G N 1992. A Gospel for a new people: Studies in Matthew. Edinburgh: T \& T Clark.

Stanton, G N 1997. The Fourfold Gospel. NTS 43, 317-46.

Stanton, G N 2002. The Gospels and Jesus. 2nd ed. New York: Oxford University Press.

Stendahl, K 1968. The school of St Matthew and its use of the Old Testament. 2nd ed. Lund: Gleerup. (ASNU 20.)

Wagner, J R 2002. Heralds of salvation: Paul and Isaiah "In concert" in Romans 911. Leiden: Brill. (NovTSup 101.)

Watson, F 2004. Paul and the hermeneutics of faith. London: T \& T Clark.

Williams, R 1998. The wound of knowledge: A theological history from the New Testament to Luther and St John of the cross. Eugene, OR: Wipf and Stock.

Wright N T 1996. Jesus and the victory of God. Minneapolis, MN: Fortress. 